\title{
Influence of Clay Block Masonry Properties on the Out-of-Plane Behaviour of Infilled RC Frames
}

\author{
Filip ANIĆ, Davorin PENAVA, Damir VAREVAC, Vasilis SARHOSIS
}

\begin{abstract}
In order to determine the characteristics that govern the out-of-plane behaviour of masonry infills, two groups of wall specimens were built and tested in the laboratory. Specimens were assembled and tested as described in EN 1052-2 provisions and constitute of flexural strength for a plane of failure parallel and perpendicular to the bedjoints specimens. By obtaining data from experiments, numerical micromodels were developed to predict their mechanical behaviour. A calibration procedure undertaken and results obtained from the experimental campaign were found to be in agreement with those obtained from the numerical models. Additionally, former inplane infilled frame numerical models were tested with acquired out-of-plane calibrated material model. No significant difference was found.
\end{abstract}

Keywords: clay block masonry infill; flexural test; micromodels; out-of-plane behaviour

\section{INTRODUCTION}

Reinforced concrete (RC) frames infilled with unreinforced masonry units (URM) is a common structural practice in seismically active South Europe [5]. European earthquake design provisions Eurocode 8 [8] treat wall infill/panels as secondary elements, i.e. they do not contribute to overall seismic behaviour. However, it was known that infills contributed in seismic behaviour of RC frames even in the late 1960's. From then, interest in seismic behaviour of infilled frames has grown [3, 18, 4] on separate fields of in-plane (IP) loading, out-of-plane (OOP) loading and their combination (IP + OOP). A large amount of experimental and analytical studies have been done in the field of IP $[3,17]$, the same cannot be stated for the OOP and especially for IP + OOP interaction $[4,20]$. Moreover, the OOP field is based on analytical research of arching action, and numerical, i.e. computational research is scarce and is based on membrane and strut with centred mass models.

Consequently, this paper is a part of OOP research with the intention to account for properties which determine behaviour of infills subjected to OOP loading. Accordingly, 20 masonry wall specimens were tested and associated numerical micro models were calibrated to account for the experiment.

\section{METHODS, MATERIALS AND RESULTS OF TESTED WALL SPECIMENTS}

\subsection{Experiment Preparation}

The experiment preparation and testing was done in accordance with EN 1052-2 [6]. Two testing groups were made: Group I: flexural strength for a plane of failure parallel to the bedjoints, and Group II: flexural strength for a plane of failure perpendicular to the bedjoints (parallel to headjoints). The recommendation of 10 wall test specimens for each Group was adopted in favour of statistical significance [16]. Wall specimens are made from whole and half-length blocks (Fig. 2).

Firstly, hollow clay masonry units (Fig. 1a) were cut in half of their height (Fig. 1b) to emulate infill units used in research performed by [12] and units that will be used in further experiments.
Mortar joints have designated M5 class according to EN 1996-1-1 [9] and nominal $10 \mathrm{~mm}$ thickness.

Pretested properties of clay blocks, mortar and wall specimens are presented in Tab. 1.

Test setup of masonry wall specimens can be seen in Figs. 2, 4c \& 4f. The average dimensions of 10 specimens in each group as well as test setup dimensions are shown in Fig. 2. Testing was conducted with an increasing monotonic load on a 4-point ( 2 line reactions +2 line loads) load setup on Controls 50-C1201/BFR by 50-C1200/8 apparatus.

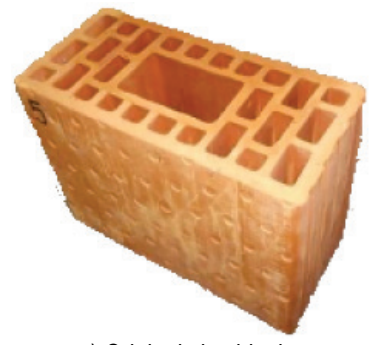

a) Original clay block

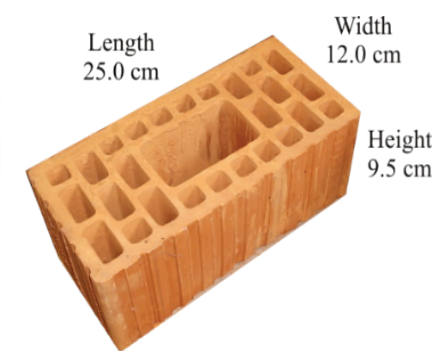

b) Modified clay block
Figure 1 Masonry unit

Table 1 Pretested material properties [13]

\begin{tabular}{|l|c|r|c|}
\hline \multicolumn{1}{|c|}{ Entity } & Properties & \multicolumn{1}{c|}{ Value } & Unit \\
\hline \multirow{2}{*}{ Clay block } & $f_{\mathrm{b}}$ & 15.90 & $\mathrm{MPa}$ \\
\cline { 2 - 4 } & $f_{\mathrm{bh}}$ & 2.60 & $\mathrm{MPa}$ \\
\hline \multirow{3}{*}{ Mortar } & $f_{\mathrm{m}}$ & 5.15 & $\mathrm{MPa}$ \\
\cline { 2 - 4 } & $f_{\mathrm{mt}}$ & 1.27 & $\mathrm{MPa}$ \\
\hline \multirow{5}{*}{ Wall specimen } & $f_{\mathrm{k}}$ & 2.70 & $\mathrm{MPa}$ \\
\cline { 2 - 4 } & $E$ & 3900.00 & $\mathrm{MPa}$ \\
\cline { 2 - 4 } & $\varepsilon_{\mathrm{u}}$ & 0.58 & $\% 0$ \\
\cline { 2 - 4 } & $f_{\mathrm{vk} 0}$ & 0.35 & $\mathrm{MPa}$ \\
\cline { 2 - 4 } & $\operatorname{tg} \alpha_{\mathrm{k}}$ & 0.24 & $\mathrm{MPa}$ \\
\hline
\end{tabular}

It was expected that specimens from Group I would fail by separating two rows of blocks on bedjoint at the mid-height of the specimen, hence reaching tensile strength of the mortar. On the other hand, two possible failures were expected for specimens from Group II: a) separation of blocks (blocks are undamaged) or b) failure through the specimens (blocks failed). The b) failure is more likely to happen as $f_{\mathrm{mt}}>f_{\text {bh }}$. 

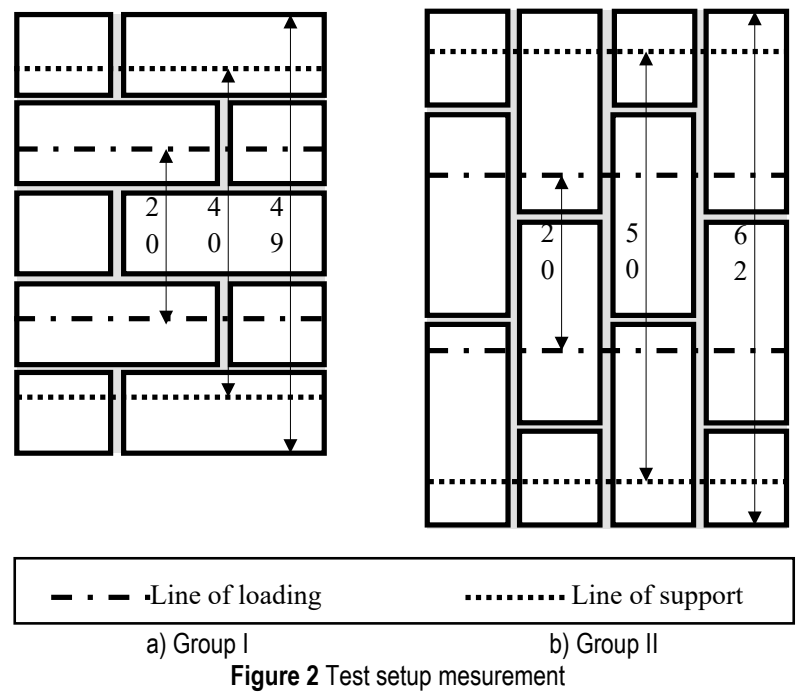

\subsection{Experimental Results}

Average results of the conducted test can be seen in Tab. 2 and its distribution in Fig. 3. Fig. 3 shows the minimum (MIN), maximum (MAX) and mean strength (AVG) with its variation within standard deviation (straight lines), i.e. $f_{\mathrm{x}} \pm s$. Flexural strength was calculated using equation 1 from [6]. Group I failed by separation of block rows on the bedjoint at the specimens mid-height (Fig. 4d \& 4e). Group II failed by failing clay blocks (Fig. $4 \mathrm{~g} \& 4 \mathrm{~h})$, hence, through the whole wall specimen.

Table 2 Mean reults from flexular test
\begin{tabular}{|c|c|c|c|}
\hline Properties & Group I & Group II & Unit \\
\hline$F_{\max }$ & 4.07 & 6.69 & $\mathrm{kN}$ \\
\hline$f_{\mathrm{x}}($ Eq. (1)) & 0.21 & 0.38 & $\mathrm{MPa}$ \\
\hline$s$ & 0.07 & 0.06 & $\mathrm{MPa}$ \\
\hline$c_{\mathrm{v}}$ & 0.28 & 0.18 & $/$ \\
\hline
\end{tabular}

$f_{x}=\frac{3 F_{\max }\left(l_{1}-l_{2}\right)}{2 b t}$

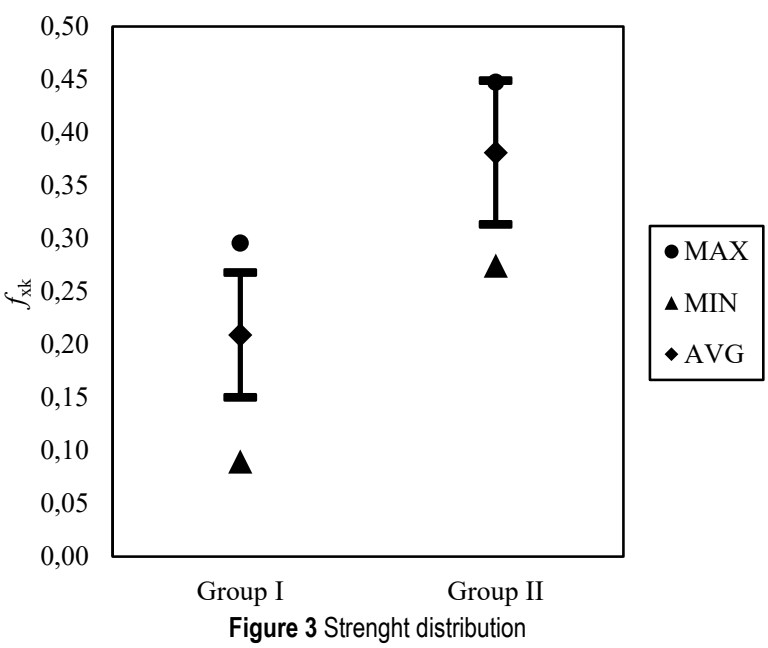

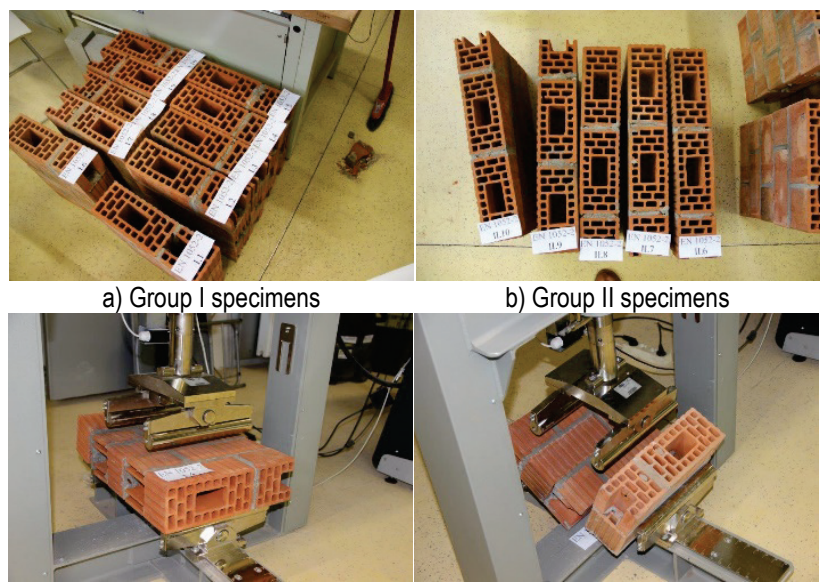

c) Group I test setup

d) Group I failure

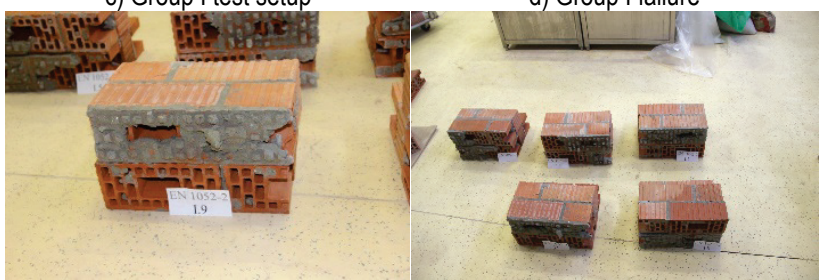

e) Typical failure of Group I
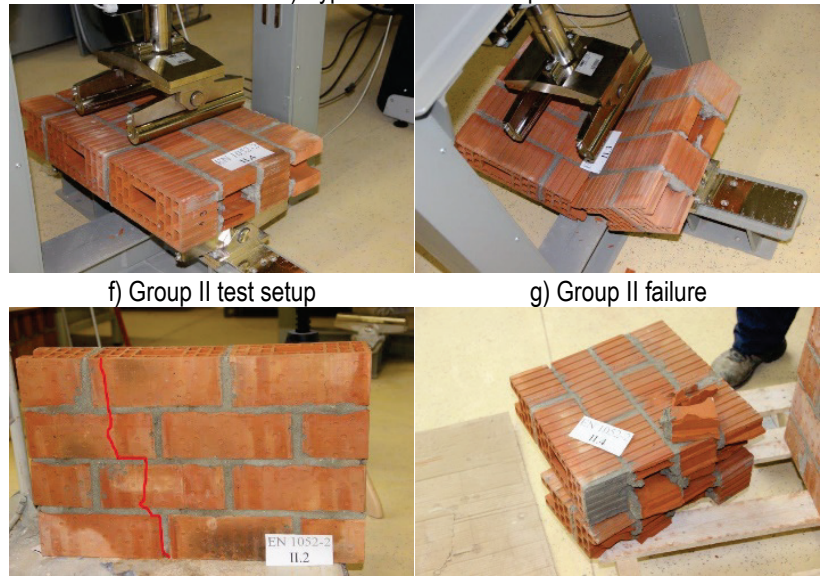

h) Typical failure of Group II

Figure 4 Test setup and failure modes

\section{METHODS, MATERIALS AND RESULTS OF NUMERICAL MODEL \\ 3.1 Numerical Model}

Numerical models were created and tested using Atena 3D Eng [11]. A three-dimensional micro modeling approach was used, with three-dimensional solid and twodimensional contact - interface (zero thickness) elements (Fig. 5). The creation of numerical model was carried out by assembling solid elements (geometry as in Fig. 1b), they are joined by zero thickness interface elements, thus, the dimensions of the numerical model and real specimens (Fig. 2) differ. Distance between loading (Fig. 6) was adopted from experiments.

Fig. 6 shows numerical model with its boundary conditions. The wall specimens were simply supported and each step was loaded with uniform line load in $-z$ direction. When uniform loads in Fig. 6 are multiplied by the length of their span, the force corresponds to $0.5 \mathrm{kN} /$ stepforce each.

Furthermore, solid elements beyond the supports in the numerical model (Fig. 6) were discarded in order to gain shorter calculation time. It is to be noted that the 
calculation with solids continuing beyond the supports was carried out, and no significant differences was observed from those without solids beyond supports.
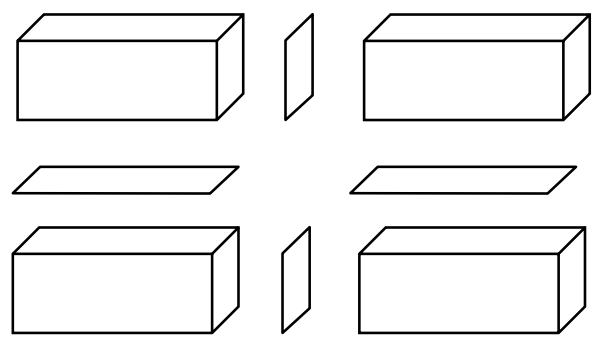

3D Solid + 2D Interface +3 S Solid

Figure 5 Micromodel composition

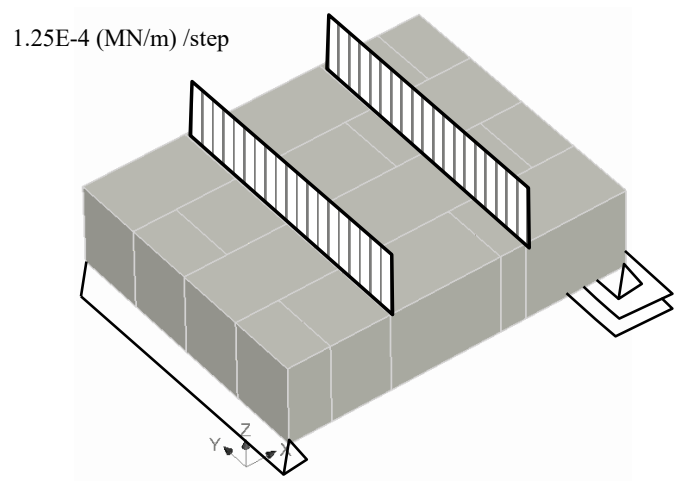

a) Group I

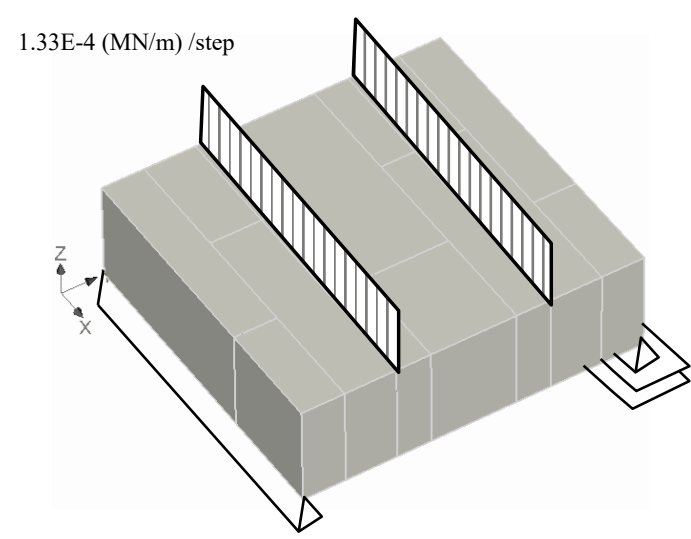

b) Group II

Figure 6 Numerical model setup

\subsection{Numerical Material Models and Calibration}

Numerical material models (Tab. 3 \& 4) were adopted from [14] and modified during the calibration. The CC nonlinear cementitious 2 material model from Tab. 3 was used for modelling clay masonry units, hence, solid elements. Likewise, $\mathrm{CC}$ interface material model from Tab. 4 was used to model the mortar joints, hence, 2D interface gap elements. The interlocking effect of mortar filling the voids of opposite blocks and thereby locking them is modelled by interlocking function (Fig. 7).

$$
\begin{aligned}
& G_{\mathrm{f}}=0.000025 \cdot f_{\mathrm{t}} \\
& K_{\mathrm{nn}}=\frac{E}{t}
\end{aligned}
$$

$$
K_{\mathrm{tt}}=\frac{G}{t}
$$

The previously mentioned models from [14] adopted clay blocks properties in the direction of voids. However, the analysis of numerical tests, regarding Group II specimens, has shown that those properties produced greater maximal force than those measured by experiments. To that end, changes to tensile strength and tension softening function were introduced. Tensile strength was changed from that in the direction of voids $f_{\mathrm{t}}$ $=1.80 \mathrm{MPa}$ to that of perpendicular to the voids $f_{\mathrm{t}}=0.38$ $\mathrm{MPa}$ as the OOP loading caused failure of the clay blocks in direction perpendicular to voids. The displacement tension softening function through trial and error was adjusted from $d=0.010 \mathrm{~mm}$ to $d=0.001 \mathrm{~mm}$. Fracture energy calculation depends upon tensile strength (Eq. (1)) [19], however it was left unchanged, i.e. as if tensile strength in eq. 1 was in the direction of voids. If tensile strength in eq. 1 is changed to be perpendicular to the voids, a predeveloped failure occurs in both Groups.

Table 3 CC Nonlinear Cementitious 2 model [10]

\begin{tabular}{|c|c|c|c|}
\hline \multirow{2}{*}{ Symbol } & Mortar bedjoint & Mortar headjoint & \multirow{2}{*}{ Unit } \\
\hline & Value & Value & \\
\hline$K_{\text {nn }}$ (Eq. (2)) & $5.65 \mathrm{E}+05$ & $8.50 \mathrm{E}+04$ & $\mathrm{MN} / \mathrm{m}^{2}$ \\
\hline$K_{\mathrm{tt}}$ (Eq. (3)) & $2.57 \mathrm{E}+05$ & $3.86 \mathrm{E}+04$ & $\mathrm{MN} / \mathrm{m}^{2}$ \\
\hline$f_{\mathrm{t}}$ & 0.20 & 0.20 & $\mathrm{MPa}$ \\
\hline$c$ & 0.35 & 0.35 & $\mathrm{MPa}$ \\
\hline $\operatorname{tg} \alpha$ & 0.24 & 0.24 & 1 \\
\hline Interlocking & see Fig. 7 & / & \\
\hline
\end{tabular}

\begin{tabular}{|c|r|c|}
\hline Properties & \multicolumn{1}{|c|}{ Value } & Unit \\
\hline$E$ & $5.650 \mathrm{E}+03$ & $\mathrm{MPa}$ \\
\hline$\mu$ & 0.100 & $/$ \\
\hline$f_{\mathrm{t}}$ & 0.380 & $\mathrm{MPa}$ \\
\hline$f_{\mathrm{c}}$ & $-1.750 \mathrm{E}+01$ & $\mathrm{MPa}$ \\
\hline$G_{\mathrm{f}}(\mathrm{Eq.}(1))$ & $4.500 \mathrm{E}-04$ & $\mathrm{MN} / \mathrm{m}$ \\
\hline$W_{\mathrm{d}}$ & $-5.000 \mathrm{E}-04$ & $/$ \\
\hline$\varepsilon_{\mathrm{cp}}$ & $-1.358 \mathrm{E}-03$ & $/$ \\
\hline$r_{\mathrm{c}, \mathrm{lim}}$ & 0.800 & $/$ \\
\hline$S_{\mathrm{F}}$ & 20.000 & $/$ \\
\hline Crack model coefficient & 1.000 & $/$ \\
\hline
\end{tabular}

Table 4 CC 3D interface model [10]

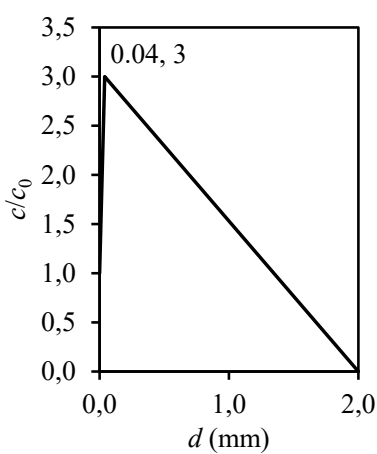

a) Interlock function

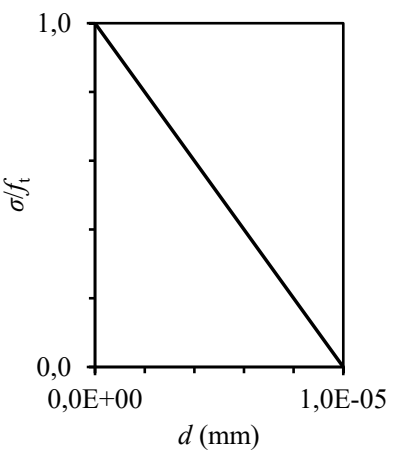

b) Tension softening
Figure 7 Interface functions

\subsection{Numerical Test Results}

With changes to the material models, the results from numerical tests are shown in Fig. 8 and Tab. 5. Tab. 5 shows the force at failure and maximal principal stress obtained from Fig. 8. 

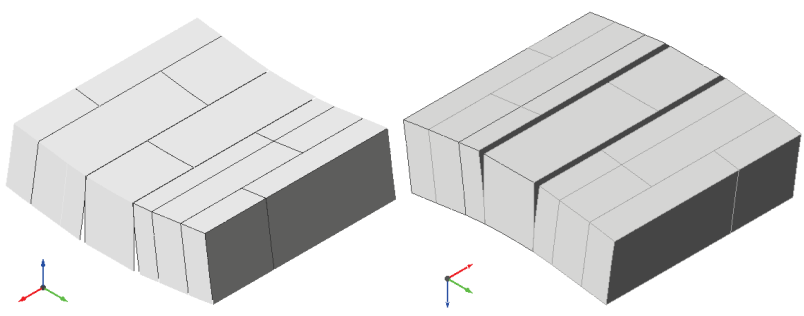

a) Deformed model Group I
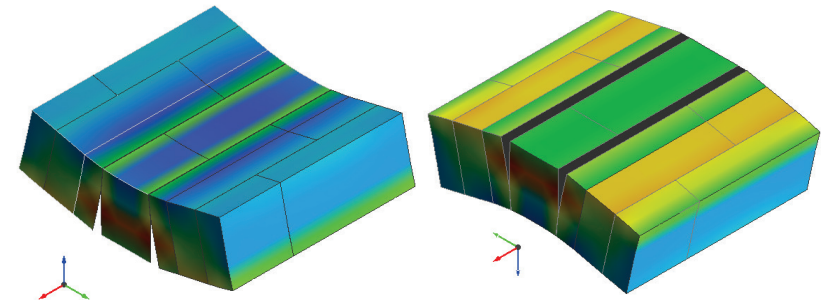

0.16 $6.6 \mathrm{E}-2 \quad-0.04 \quad(\mathrm{MPa})$

b) Max. principal stress Group
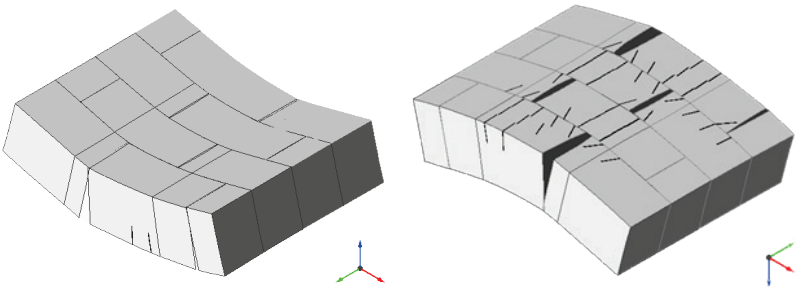

c) Deformed model Group II
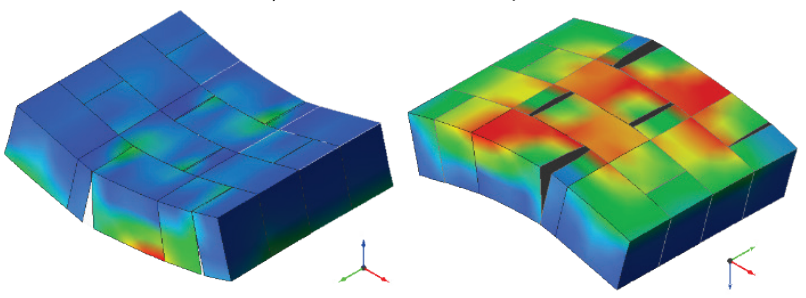

0.37

0.20

$-0.03(\mathrm{MPa})$

d) Max. principal stress Group II

\begin{tabular}{|ll|}
\hline Deformation $\times 300$ & Min. crack width $0.001 \mathrm{~mm}$ \\
Crack width multiplier $\times 1$ & Shift crack outwards $\times 0$ \\
\hline
\end{tabular}

Figure 8 Numerical test results at $F_{\max }$

Table 5 Results from numerical tests

\begin{tabular}{|c|c|c|}
\multicolumn{3}{|c|}{ Table 5 Results from numerical tests } \\
\hline Group & $F_{\max }(\mathrm{kN})$ & $\sigma_{\max }(\mathrm{MPa})$ \\
\hline I & 4.50 & $/$ \\
\hline II & 6.20 & 0.37 \\
\hline
\end{tabular}

From Fig. 8a it can be observed that numerical model of Group I had failure by discontenting bedjoints, i.e. mortar tensile failure. Fig. 8c shows failures and cracking of the clay blocks.

\section{ADDITIONAL INVESTIGATION ON INFILLED FRAME 4.1 General Information}

Having material model properties changed and adjusted, previous work with unreinforced masonry infilled (URM) RC frames [1, 2, 15] was questioned. Hence, the modifications to the infill units were implemented into the infilled frame model in order to measure the possible alterations. In short, the reinforced concrete (RC) frame has a designated medium ductility class (DCM) by Eurocode 2 provisions [7], boundary conditions with numerical test setups are presented in Fig.
9. The model was subjected as in previous works (in-plane pushover method). For more details on the infilled frame, refere to [2] paper.
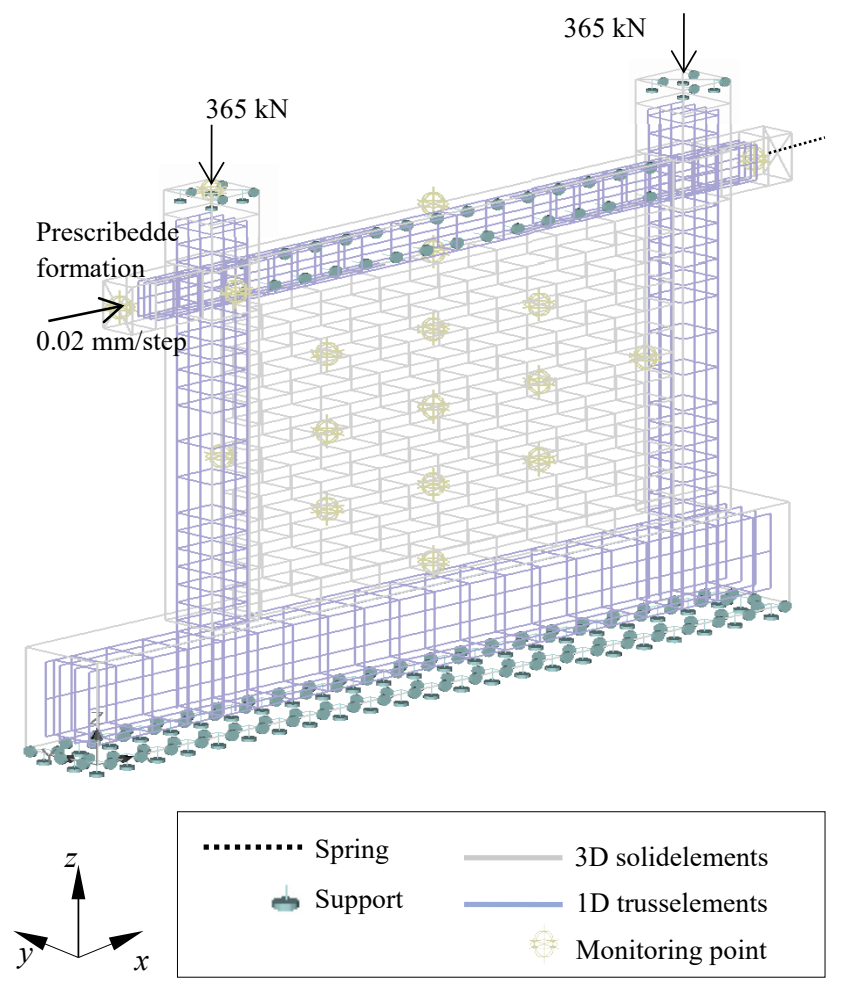

Figure 9 Infilled frame numerical model.

\subsection{Infilled Frame Numerical Test Results}

Force displacement diagrams of both infill material models are shown in Fig. 10. Cracks and minimal principal stresses for each of the two are shown in Fig. 11.

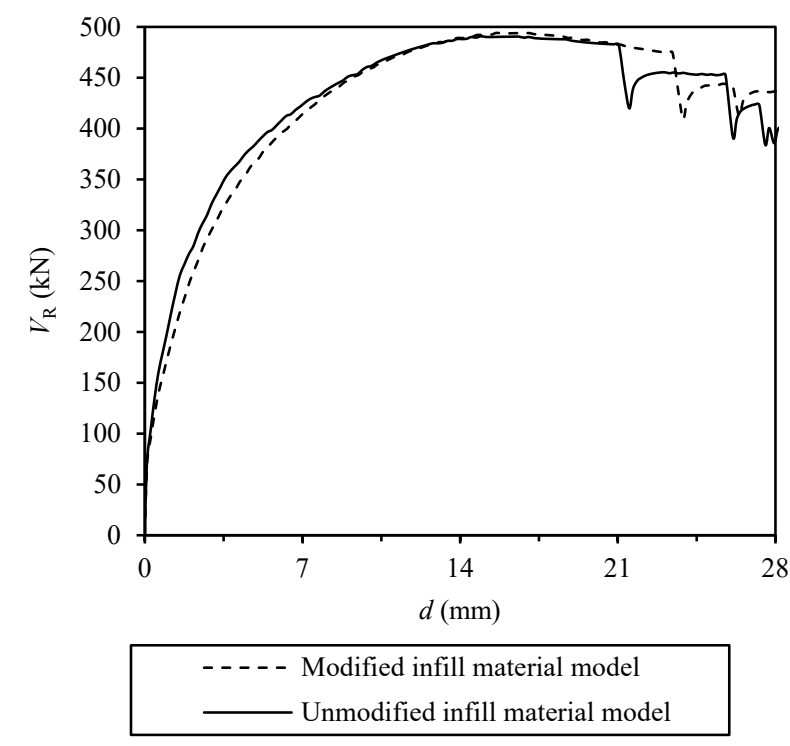

Figure 10 Force displacement diagram of infilled frame model 


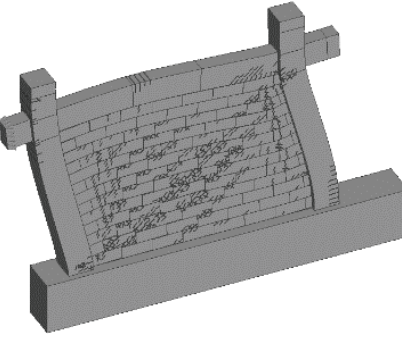

a) Unmodified infill material mode cracks

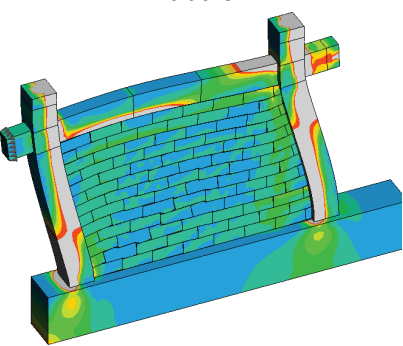

$\begin{array}{lllllllll}5.0 & 1.9 & -1.3 & -4.4 & -7.5 & -10.6 & -13.8 & -16.9 & -20.0\end{array}$ \begin{tabular}{|llllllll}
\hline & 1 & 1 & 1 & I & I & I & 1
\end{tabular}

c) Unmodified infill material model min. d) Modified infill material model min. principal stress principal stress

Deformation scale $\times 10 \quad$ Crack width multiplier $\times 1$

Min. crack width $\times 1 \mathrm{E}-4 \mathrm{~m} \quad$ Shift cracks outwards $\times 0$

Figure 11 Infilled frame numerical model results at $d=28 \mathrm{~mm}$

\section{CONCLUSIONS AND DISCCUSION OF THE RESULTS}

By comparing numerical and experimental results of Group I \& II, the difference of maximal forces was calculated as $9.55 \%$ for Group I and $7.32 \%$ for Group II. Group II has $2.63 \%$ difference in maximal stress.

Based on flexural testing of masonry wall specimens a numerical model was compiled and calibrated. Calibration included modifying tension strength and displacement in tension softening function. Tension strength was changed from the value in direction of voids to the value perpendicular to voids. The calibration has proven adequate enough to have high correlation with the experiments. It is to be noted that the calibration was carried out in favour of Group II as Group I due to the specific failure mode (reaching tensile strength of mortar) had agreement with the experiments from beginning.

Additionally, an infilled frame was tested in order to observe the validity due to changes in material model of clay blocks. It was shown that the changes did not drastically affect the outcome force (Fig. 10), crack and stress (Fig. 11).

In summation, the following conclusions can be drawn:

a) Wall specimens had failure modes as predicted, Group I had failure along bedjoints due to reaching mortar tensile strength. Group II failed through the blocks, reaching tensile strength of the blocks in direction perpendicular to the voids.

b) In order to simulate OOP bending, a mix of mechanical properties had to be implemented into the material models. Tensile strength of clay masonry unit was set to have the value perpendicular to the voids, end displacement in tension softening function was lowered, other properties have mechanical values in direction of voids. c) Numerical models of Group I \& II had failure mechanism same as the experimental ones (Fig. $4 \&$ 8). Likewise, the numerical results force and stress wise have satisfying degree of agreement.

d) When the load is parallel to bedjoints, governing element are the bedjoints, more exactly mortar tensile strength. On the other hand, when the load is parallel to headjoints, the governing elements are properties of the clay block, i.e. its tensile strength.

e) The changes of material models had no significant effect on the URM frame model in regard to crack and stress pattern as well as force - displacement curve.

f) Regarding the changes to numerical model of clay masonry block and its unneglectable effect to the IP pushover analysis of URM frames it is obvious that the main governing element of URM frames are interfaces, more exactly bedjoint.

\section{$6 \quad$ LIST OF SYMBOLS}

\section{Test specimens}

$l_{1} \quad$ Distance between supports

$l_{2} \quad$ Distance between loading

$b \quad$ Specimens length

$t \quad$ Specimens thickness

Mechanical (tested) properties

$f_{\mathrm{b}} \quad$ Clay blocks normalized compression strength in direction of voids

flay blocks normalized compression strength in direction

bh perpendicular to voids

$f_{\mathrm{m}} \quad$ Mortars compressive strength

$f_{\mathrm{mt}} \quad$ Mortars flexural strength

$f_{\mathrm{k}} \quad$ Characteristic masonry wall compressive strength

E Elastic modulus of wall specimen

$\varepsilon_{\mathrm{u}} \quad$ Ultimate wall strain

$f_{\mathrm{vk} 0} \quad$ Initial shear strength

$\operatorname{tg} \alpha_{k} \quad$ Friction coefficient

$f_{x 1} \quad$ Flexural strength for a plane of failure parallel to the

$f_{\mathrm{x} 1} \quad$ bedjoints- Group I

Flexural strength for a plane of failure perpendicular to the

$f_{\mathrm{x} 2} \quad$ bedjoints (parallel to headjoints) - Group II

$s \quad$ Standard deviation (STDEV)

$c_{\mathrm{v}} \quad$ Variation coefficient Numerical material properties

E Elastic Modulus

$\mu \quad$ Poisson's coefficient

$f_{\mathrm{t}} \quad$ Tensile strength

$f_{\mathrm{c}} \quad$ Compressive strength

$G_{\text {f }} \quad$ Fracture Energy

$W_{\mathrm{d}} \quad$ Plastic displacement

$\varepsilon_{\mathrm{cp}} \quad$ Strain at $f_{\mathrm{c}}$

$r_{\mathrm{c}, \mathrm{lim}} \quad$ Maximal strength reduction under the large transverse strain

$S_{\mathrm{F}} \quad$ Shear factor coefficient that defines a relationship between normal and shear crack stiffness.

$K_{\mathrm{nn}} \quad$ Normal interface stiffness

$K_{\mathrm{tt}} \quad$ Tangential interface stiffness

c Cohesion

$\operatorname{tg} \alpha \quad$ Friction coefficient

$V_{\mathrm{R}} \quad$ Shear force

d Displacement

\section{REFERENCES}

[1] Anić, F., Penava, D., Legatiuk, D., \& Sarhosis, V. (2017). Influence of variability in materials used on seismic response of masonry infilled reinforced concrete frames. In Osmi susret Hrvatskog društva za mehaniku (pp. 1-9). Osijek, Croatia. Retrieved from http://bib.irb.hr/prikazi$\mathrm{rad} ? \mathrm{rad}=885880$

[2] Anić, F., Penava, D., \& Sarhosis, V. (2017). Development of a three-dimensional computational model for the in-plane 
and out-of-plane analysis of masonry-infilled reinforced concrete frames. In $6^{\text {th }}$ International Conference on Computational Methods in Structural Dynamics and Earthquake Engineering. Rhodes Island, Greece.

[3] Asteris, P. G., Antoniou, S. T., Sophianopoulos, D. S., \& Chrysostomou, C. Z. (2011). Mathematical macromodeling of infilled frames: state of the art. Journal of Structural Engineering, 137(12), 1508-1517. https://doi.org/10.1061/(ASCE)ST.1943-541X.0000384

[4] Asteris, P. G., Cavaleri, L., Di Trapani, F., \& Tsaris, A. K. (2017). Numerical modelling of out-of-plane response of infilled frames: State of the art and future challenges for the equivalent strut macromodels. Engineering Structures, 132, 110-122. https://doi.org/10.1016/j.engstruct.2016.10.012

[5] Booth, E. \& Key, D. (2006). Earthquake Design Practice for Buildings. London: Thomas Telford. Retrieved from http://ebooks.cambridge.org/ref/id/CBO9781107415324A0 09

[6] British Standards Institution. (2016). BS EN 1052-2. Methods of test for masonry Part 2: Determination of flexural strength.

[7] CEN. (2004a). Eurocode 2: Design of concrete structures Part 1-1: General rules and rules for buildings (EN 1992-11:2004). Brussels: European Committee for Standardization.

[8] CEN. (2004b). Eurocode 8: Design of Structures for Earthquake Resistance - Part 1: General Rules, Seismic Actions and Rules for Buildings (EN 1998-1:2004). Brussels: European Committee for Standardization.

[9] CEN. (2005). Eurocode 6: Design of masonry structures Part 1-1: General rules for reinforced and unreinforced masonry structures (EN 1996-1-1:2005). Brussels: European Committee for Standardization

[10] Cervenka, V., Jendele, L., \& Cervenka, J. (2012). ATENA Program Documentation Part 1 Theory. Prague: Cervenka Consulting Ltd.

[11] Cervenka Consulting. (2015). ATENA for Non-Linear Finite Element Analysis of Reinforced Concrete Structures. Prague: Červenka Consulting s.r.o.

[12] Penava, D. (2012). Influence of openings on seismic response of masonry infilled reinforced concrete frames.

[13] Penava, D., Radić, I., Gazić, G., \& Sigmund, V. (2011). Mechanical properties of masonry as required for the seismic resistance verification. Tehnički vjesnik-Technical Gazette, 18(2), 273-280.

[14] Penava, D., Sigmund, V., \& Kožar, I. (2016). Validation of a simplified micromodel for analysis of infilled RC frames exposed to cyclic lateral loads. Bulletin of Earthquake Engineering, 14(10), 2779-2804. https://doi.org/10.1007/s10518-016-9929-0

[15] Sarhosis, V. (2016). Optimisation procedure for material parameter identification for masonry constitutive models. International Journal of Masonry Research and Innovation, 1(1), 48. https://doi.org/10.1504/IJMRI.2016.074735

[16] Sorić, Z. (2016). Zidane konstrukcije. Zagreb: Sveučilište u Zagrebu.

[17] Teni, M., Grubišić, M., \& Guljaš, I. (2014). Simplified Approaches for Modeling Infilled Frames. Elektronički Časopis Građevinskog Fakulteta Osijek, 70-88. https://doi.org/10.13167/2014.9.8

[18] Di Trapani, F., Macaluso, G., Cavaleri, L., \& Papia, M. (2015). Masonry infills and RC frames interaction: literature overview and state of the art of macromodeling approach. European Journal of Environmental and Civil Engineering, 19(9), 1059-1095. https://doi.org/10.1080/19648189.2014.996671

[19] Vos, E. (1983). Influence of loading rate and radial pressure on bond in reinforced concrete. A numerical and experimental approach. Thesis.
[20] Wang, C., Forth, J. P., Nikitas, N., \& Sarhosis, V. (2016) Retrofitting of masonry walls by using a mortar joint technique; experiments and numerical validation. Engineering Structures, 117, 58-70. https://doi.org/10.1016/j.engstruct.2016.03.001

\section{Contact information}

Filip ANIĆ, mag. ing. aedif.

Josip Juraj Strossmayer University of Osijek, Faculty of Civil Engineering and Architecture Vladimira Preloga 3, 31000 Osijek, Croatia filip.anic@gfos.hr

doc. dr. sc. Davorin PENAVA, dipl. ing. građ. (Corresponding author)

Josip Juraj Strossmayer University of Osiiek, Faculty of Civil Engineering and Architecture, Vladimira Preloga 3, 31000 Osijek, Croatia

davorin.penava@gfos.hr

izv. prof. dr. sc. Damir VAREVAC, dipl. ing. građ

Josip Juraj Strossmayer University of Osijek, Faculty of Civil Engineering and Architecture, Vladimira Preloga 3, 31000 Osijek, Croatia damir.varevac@gfos.hr

doc. dr. sc. Vasilis SARHOSIS, dipl. ing. građ. Newcastle University, School of Engineering Drummond Building, Newcastle upon Tyne, NE1 7RU, United Kingdom vasilis.sarhosis@ncl.ac.uk 